\title{
Trends of potential years of life lost due to main causes of deaths in urban and rural population in Poland, 2002-2011
}

\author{
Michalina Krzyżak1, Dominik Maślach'1, Andrzej Szpak', Katarzyna Piotrowska², \\ Katarzyna Florczyk ${ }^{3}$, Martyna Skrodzka ${ }^{3}$, Alfred Owoc ${ }^{4,5}$, Iwona Bojar \\ ${ }^{1}$ Department of Public Health, Faculty of Health Sciences, Medical University, Bialystok, Poland \\ ${ }^{2}$ Department of Hygiene and Epidemiology, Faculty of Health Sciences, Medical University, Bialystok, Poland \\ ${ }^{3}$ Students' Scientific Group of Public Health, Department of Public Health, Medical University, Bialystok, Poland \\ ${ }^{4}$ College of Public Health, Zielona Góra, Poland \\ ${ }^{5}$ Centre of Public Health and Health Promotion, Institute of Rural Health, Lublin, Poland \\ ${ }^{6}$ Institute of Rural Health, Lublin, Poland
}

Krzyżak M, Maślach D, Szpak A, Piotrowska K, Florczyk K, Skrodzka M, Owoc A, Bojar I. Trends of potential years of life lost due to main causes of deaths in urban and rural population in Poland, 2002-2011. Ann Agric Environ Med. 2015; 22(3): 564-571. 10.5604/12321966.1168657

\begin{abstract}
The aim of the study was to analyse the level and the trends of Potential Years of Life Lost due to main causes of deaths in Poland in 2002-2011, with consideration of place of residence, urban-rural. The material for the study was the number of deaths due to main causes in Poland in years 2002-2011, based on data from the Central Statistical Office. Premature mortality analysis was conducted with the use of PYLL indicator (PYLL - Potential Years of Life Lost). PYLL rate was calculated according to the method proposed by J. Romeder, according to which the premature mortality was defined as death before the age of 70. Time trends of PYLL rate and the annual percent change (APC) were assessed using the Joinpoint Regression Programme. Rural/urban ratio was used to presented the differences in premature mortality between rural and urban areas. In years2002-2011, the PYLL rate for all-cause deaths decreased by $13.2 \%$ among men and $16.0 \%$ among women in rural areas, whereas in urban decreased it decreased by $15.7 \%$ among men and $14.9 \%$ among women. In 2011, the main causes of PYLL among men in rural areas were: external causes (32.3\%), cardiovascular diseases (23.5\%) and cancers (19.4\%); in urban areas: cardiovascular diseases (24.7\%), external causes (24.3\%) and cancers (20.9\%). Among women in rural areas, the leading causes were: cancers (39.9\%), cardiovascular diseases (20.1\%) and external causes (15.1\%). The main causes of premature mortality among women in urban areas were: cancers (41.7\%), cardiovascular diseases (19.6\%) and external causes (11.1\%). Premature mortality among men in rural areas was significantly higher than in urban for all analysed causes of death, with the exception of ischaemic heart diseases and colorectal cancer. Premature mortality among women in rural areas was significantly lower than in urban for all analysed cause of deaths, except of cerebrovascular diseases, external causes, suicides and traffic accidents. The presented epidemiological situation for premature mortality indicate differences in the state of health of the inhabitants in urban and rural areas in Poland. The leading causes of premature mortality are caused by preventable deaths, which leads to a need to intensify measures in primary and secondary prevention.
\end{abstract}

\section{Key words}

health inequalities, Potential Years of Life Lost, premature mortality, preventable deaths, urban-rural population

\section{INTRODUCTION}

Inequalities in health are found across the whole of Europe [1]. The main reasons for this are socioeconomic disparities. In Poland, and in other economic transition countries, one of the most important factors determining socioeconomic status is place of residence (urban-rural) [2], its impact on health might be associated with the environment, social and demographic factors, lifestyle, and also access to health care, prevention, early detection of diseases and treatment. Factors related to place of residence may also have different effects on men and women, the young and the old. Urbanrural inequalities in health have long been present and are an important area of public health research in Poland [3, 4, $5,6,7,8]$. Reduction of health inequalities, including those

Address for correspondence: Michalina Krzyżak Department of Public Health, Faculty of Health Sciences, Medical University, Bialystok, Szpitalna 37, 15-295 Białystok, Poland

E-mail:michalina.krzyzak@umb.edu.pl

Received: 03 July 2015; accepted: 02 September 2015 between urban and rural, is also one of the most important goals for public health policy in Poland [9]. Assessment of their effectiveness requires monitoring and comparing the health situation between populations.

The concept of preventable deaths assumes that the aim of the public health strategies is to save lives; first of all, by the avoidance of premature deaths which would not occur whenever it had been possible to prevent, detect early and treat illnesses, as well as provide rehabilitation thanks to health education, health care and health promotion $[10,11]$.

The traditional premature mortality indicator shows the rate of deaths in a population, allows the analysis of time trends and comparison of premature mortality in various populations; however, it does not include the social and economic burdens of premature deaths imposed on society. Therefore, the PYLL (Potential Years of Life Lost) rate was introduced, which is an addition to the premature mortality analysis as it includes the number of deaths resulting from a particular cause, as well as the age at death $[12,13]$. 
The PYLL rate is an indicator which arbitrarily assumes life expectancy, e.g. in OECD countries this is set at the age of 70 [14]. In considering a death at the age of 20 , it is accountable for 50 potential years of life lost. Therefore, deaths in younger age groups cause a greater social and economic loss burden because they are the reason for more potential years of life lost.

The purpose of the study was to analyse the level and the trends of Potential Years of Life Lost due to main causes of deaths in Poland in 2002-2011, with consideration of place of residence, urban-rural.

\section{MATERIALS AND METHOD}

The material was based on data from the Central Statistical Office of Poland on the number of deaths registered in urban and rural population in 2002-2011. Causes of deaths were coded according to the $10^{\text {th }}$ revision of the International Classification of Diseases [15].

'Urban area' was defined by the Central Statistical Office as an area having the status of a town, established in accordance with the relevant legal Act. The population of Poland between 2002-2011 consisted, on average, of 38,235,267 inhabitants, $61.2 \%$ of whom were living in urban areas [16].

Potential Years of Life Lost (PYLL) were calculated according to the method proposed by J. Romeder [12].

The number of deaths in 5-year age groups was used to calculate PYLL in Poland in 2002-2011. The calculations were made according to the formula:

$$
\text { PYLL }=\sum_{i=1}^{70} \mathrm{~d}_{i} \mathrm{x}(70-i)
$$

where

70 - is the cut-off age before the death occurrence;

$\mathrm{i}$ - is the average number of potential years of life lost due to death causes registered at the given age group (e.g. 32.5 years for the age group 15-19);

$\mathrm{d}_{\mathrm{i}}-$ is the number of deaths in $i$ age group.

PYLL rate was calculated as a quotient of the PYLL number and the number of inhabitants in urban and rural in the age group 1-69. PYLL rate was calculated per 100,000 people, separately for both genders.

Age-standardised PYLL rate was also calculated. Standardization for age was performed by the direct method using the European population as the standard.

Time trends for the age-standarised PYLL rate in years 2002-2011 were analysed for general-causes of deaths and 3 main categories of deaths: cancer, cardiovascular diseases, and external causes. Moreover, some causes with a more relevant impact on premature mortality were selected from the main causes of deaths. The category of causes of death used in the analysis is shown in Table 1.

The changes in PYLL rates for each cause were analysed using joinpoint models. This method is an extension of the linear regression model, in which the time trend is determined by the joined segments (joinpoints) in which changes in time trends occur in a statistically significant way [17].

On the basis of the linear regression model, in which the natural logarithm of PYLL rate was a dependent variable, and the calendar year was an independent variable

$(y=a+b x$. where $y=\ln ($ PYLL rate). $x=$ calendar year $)$.
Table 1. Categories of causes of death used in the analysis

\begin{tabular}{lc}
\hline Categories of causes of death & Classification of diseases according to ICD 10 \\
\hline All causes & A02.0- Y89.9 \\
\hline Cancer & C00-C97 \\
\hline Colorectal cancer & C18-C21 \\
\hline Lung cancer & C33-C34 \\
\hline Breast cancer & C50 \\
\hline Cervical cancer & C53 \\
\hline Cardiovascular diseases & $100-199$ \\
\hline Ischemic heart diseases & $120-125$ \\
\hline Cerebrovascular diseases & $160-169$ \\
\hline External causes & V01 - Y89 \\
\hline Traffic accidents & V01 - V99 \\
\hline Suicides & X60 - X84 \\
\hline
\end{tabular}

The annual percent change (APC) of PYLL rate for each trend was determined according to the following formula:

$$
\mathrm{APC}=100 *\left(\exp ^{\mathrm{b}}-1\right)
$$

A confidence interval of $95 \%$ was set in order to estimate the statistical significance of APC level in the analysed period.

The trends were analysed using the Joinpoint Regression Programme (Version 4.0.4, May 2013) [18].

Differences in PYLL rate between urban and rural areas were presented with the use of the rural/urban ratio. This was calculated as a quotient of the PYLL rate in rural and urban areas. The values of rural/urban ratio and $95 \%$ confidence interval were determined using the Health Disparities Calculator (Version 1.2.4, October 2013) [19].

\section{RESULTS}

In 2002-2011, the PYLL rate for men for all-cause deaths decreased in urban and rural areas, but in both populations occurred significant changes in 2008, in urban areas by $4.5 \%$ per year $(\mathrm{p}<0.05)$ and in rural areas by $3.8 \%$ per year $(\mathrm{p}<0.05)$ (Tab. 2).

In 2011, among men in urban areas, the main causes of premature mortality were cardiovascular diseases, responsible for $24.7 \%$ of PYLL, followed by external causes $24.3 \%$ and cancers $20.9 \%$. For men in rural areas, the leading causes for premature mortality were external causes $-32.3 \%$ of PYLL, followed by cardiovascular diseases $-23.5 \%$ and cancers $-19.4 \%$.

In 2002-2011, the PYLL rate for men in urban areas systematically decreased, due to all cancers ( $\mathrm{APC}=2.8 \%$; $\mathrm{p}<0.05)$ : colorectal cancer $(\mathrm{APC}=0.9 \%$; $\mathrm{p}<0.05)$, lung cancer $(\mathrm{APC}=3.6 \% ; \mathrm{p}<0.05)$, ischemic heart diseases $(\mathrm{APC}=5.1 \%$; $\mathrm{p}<0.05)$, cerebrovascular diseases $(\mathrm{APC}=3.3 \% ; \mathrm{p}<0.05)$, external causes (APC $=2.0 \% ; \mathrm{p}<0.05)$, traffic accidents $(\mathrm{APC}=4.1 \% ; \mathrm{p}<0.05)$, and for cardiovascular diseases in $2002-2009$, by $1.2 \%$ per year $(\mathrm{p}<0.05)$ and until 2011 by $6.1 \%$ per year $(\mathrm{p}<0.05)$. For men in rural areas, premature mortality systematically decreased for all cancers (APC $=2.4 \%$; $\mathrm{p}<0.05)$, lung cancer $(\mathrm{APC}=3.7 \%$; $\mathrm{p}<0.05)$, ischemic heart diseases $(\mathrm{APC}=4.9 \% ; \mathrm{p}<0.05)$, external causes $(\mathrm{APC}=1.3 \%$; $\mathrm{p}<0.05)$ and traffic accidents $(\mathrm{APC}=3.2 \%$; $<<0.05)$, and for cerebrovascular diseases in $2002-2008$, by $2.1 \%$ per year $(\mathrm{p}<0.05)$ and then by $6.2 \%$ per year $(\mathrm{p}<0.05)$. 


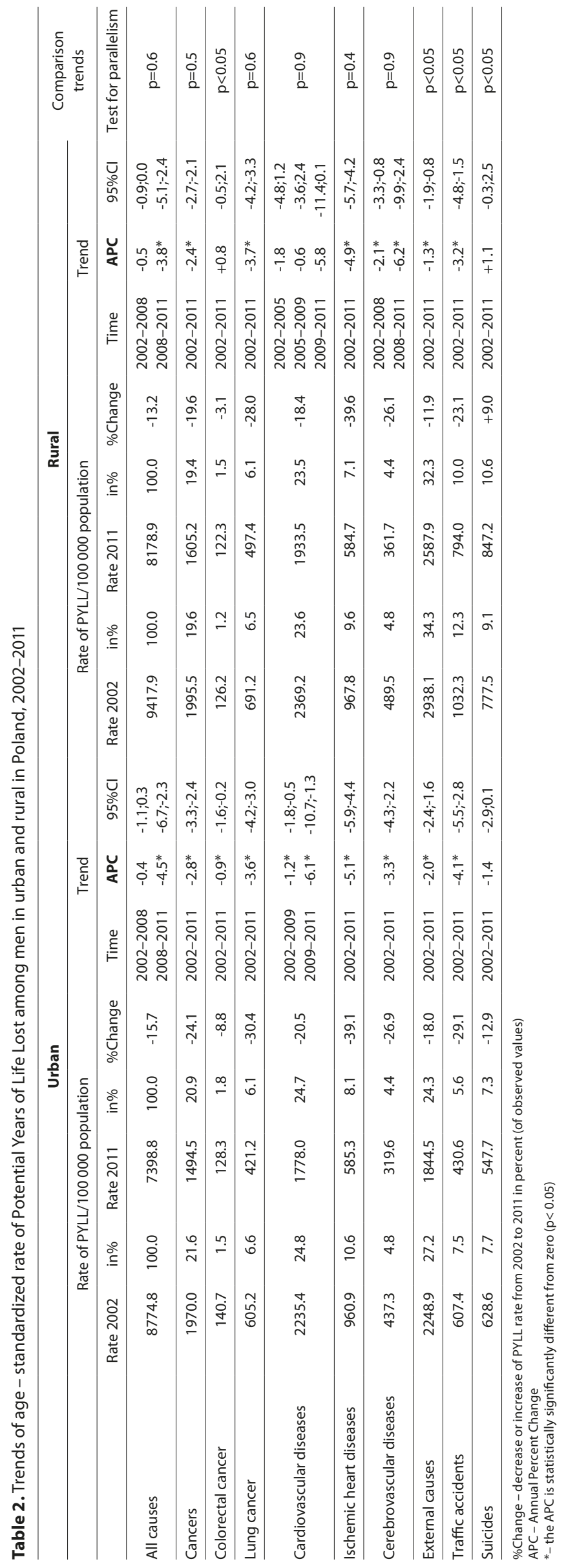




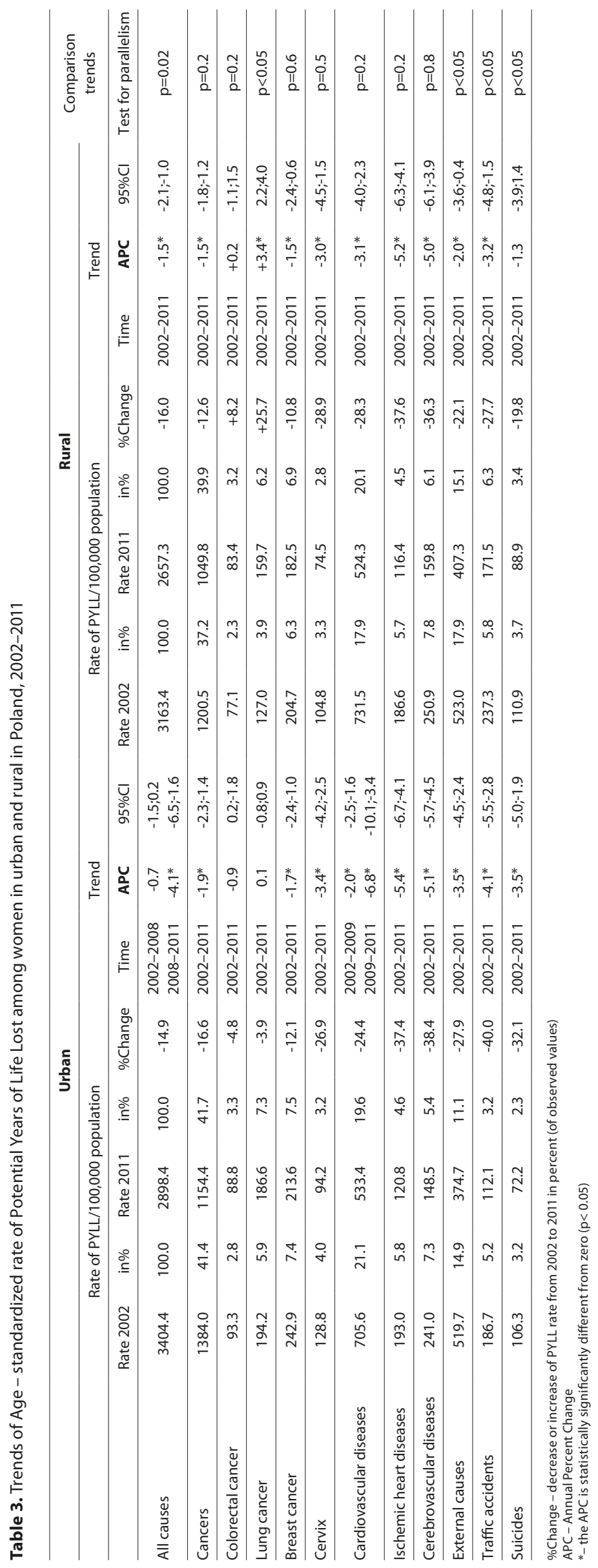


Figure 1 presents the differences in rate of PYLL between rural and urban areas using the rural/urban ratio. Premature mortality among men in rural areas was significantly higher than in urban areas for all analysed causes of death, with the exception of ischemic heart diseases and colorectal cancer. The biggest differences were due to external causes (29\%), suicides (35\%) and traffic accidents (46\%).

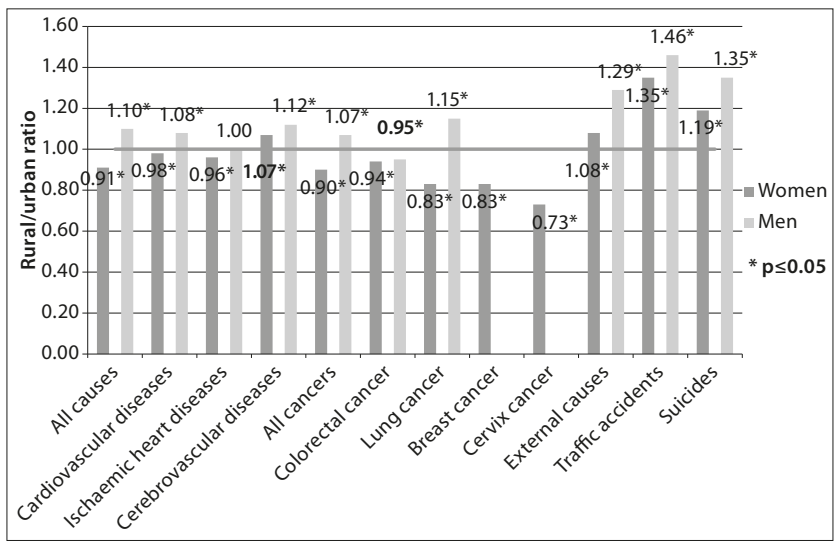

Figure 1. Rural/urban ratio of rate of PYLL among men and women in Poland in 2011

The PYLL rate for all-cause deaths was almost 3 times higher among men than women, both in the urban and rural areas (Tab. 2 and 3).

Among women in urban in 2002-2011, the PYLL rate for all-cause deaths decreased, but a significant change occurred in 2008 , by $4.1 \%$ per year $(\mathrm{p}<0.05)$. In rural areas, the PYLL rate decreased systematically in the analysed period, by $1.5 \%$ per year $(\mathrm{p}<0.05)$.

In 2002-2011, systematically positive changes were noted among women in urban areas for all cancers (APC $=1,9 \%$; $\mathrm{p}<0.05)$, breast cancer $(\mathrm{APC}=1.7 \% ; \mathrm{p}<0.05)$, cervix cancer $(\mathrm{APC}=3.4 \% ; \mathrm{p}<0.05)$, ischemic heart diseases $(\mathrm{APC}=5.4 \%$; $\mathrm{p}<0.05)$, cerebrovascular diseases $(\mathrm{APC}=5.1 \%$; $\mathrm{p}<0.05)$, external causes $(\mathrm{APC}=3.5 \% ; \mathrm{p}<0.05)$, traffic accidents $(\mathrm{APC}=4.1 \%$; $\mathrm{p}<0.05)$, suicides $(\mathrm{APC}=3.5 \% ; \mathrm{p}<0.05)$. The PYLL rate for cardiovascular diseases in 2002-2009 decreased by $2.0 \%$ per year $(p<0.05)$, and after 2009 , by $6.8 \%$ per year $(p<0.05)$.

During the analysed period, the PYLL rate decreased among women in rural areas for all cancers (APC $=1.5 \%$; $\mathrm{p}<0.05)$ : breast cancer $(\mathrm{APC}=1.5 \%$; $\mathrm{p}<0.05)$, cervical cancer $(\mathrm{APC}=3.0 \% ; \mathrm{p}<0.05)$, cardiovascular diseases $(\mathrm{APC}=3.1 \%$; $\mathrm{p}<0.05)$ ischemic heart diseases $(\mathrm{APC}=5.2 \% ; \mathrm{p}<0.05)$, cerebrovascular diseases $(\mathrm{APC}=5.0 \% ; \mathrm{p}<0.05)$, external causes $(\mathrm{APC}=2.0 \% ; \mathrm{p}<0.05)$, and traffic accidents $(\mathrm{APC}=3.2 \%$; $\mathrm{p}<0.05)$. The PYLL rate for lung cancer in 2002-2011 increased by $3.4 \%$ per year $(\mathrm{p}<0.05)$.

Premature mortality among women in rural areas was significantly lower than in urban areas for all analysed causes of deaths, with the exception of cerebrovascular diseases (7\% higher), external causes (8\% higher), suicides (19\% higher), with the biggest increase noted for traffic accidents - 35\%.

\section{DISCUSSION}

The results of the presented study indicate a continuous decrease in premature mortality in Poland. Throughout the analysed period, the PYLL rate declined for all-causes of deaths among men and women in urban and rural areas. In Poland, from the mid 1960s until the end of 1980s, premature mortality among men increased systematically, whereas among women it remained on the same level. After 1991, a slowing down was seen in the trend in both men and women, followed by a reverse change and a decrease in premature mortality [20]. The results of the research show that since 2008, the PYLL rate decreased among men in urban and rural, and among women in urban areas, due to all-causes death. Among women in rural areas, premature mortality decreased systematically in 2002-2011.

The results of the current study indicate differences in the state of health of the inhabitants in urban and rural areas, and such a diversity in health between urban and rural areas is observed worldwide. In most Western and Northen European countries, as well as in the United States, better health situations exist among inhabitants of rural areas [21, 22, 23]. In Central and Eastern European countries, the reverse prevails $[24,25,26]$.

The results of the presented study show that the place of residence affects men and women in a different way. The PYLL rate among men in rural areas was significantly higher than in urban areas for all analysed causes of death, with the exception of ischemic heart diseases and colorectal cancer. Among women, the higher level of premature mortality in rural areas occurred only for cerebrovascular diseases, external causes, traffic accidents and suicides. A similar urban-rural inequality in premature mortality was observed among the inhabitants of Lodz Province in Poland [5].

Throughout the analysed period, the PYLL rate due to allcauses of death for men, both in urban and rural areas, was higher than for women, and the differences were larger in rural areas. The biggest surplus of PYLL rate between men and women was for cardiovascular diseases (urban -8 times higher; rural -10 times higher) and suicides (urban - 7.5 times higher; rural - 9 times higher). Higher premature mortality rates for men than for women are common in all parts of the world [27]. In all EU countries, men die earlier than women, and in 2010, an average surplus in mortality among men in comparison to women amounted to approximately 65\%; in Poland, it was higher and amounted to $91 \%$. Higher mortality among men in Poland occurred in all age groups, but was the highest in those over the age of 60 [28].

The results of the research indicate that the main causes of premature mortality are preventable. In 2002, the structure of causes of premature mortality for men in urban and rural areas was similar, and the prime category of causes for potential years of life lost before the age of 70 were external causes, cancers and cardiovascular diseases. In 2011, the leading causes of premature mortality among men in urban areas were cardiovascular diseases, but in rural areas the structure did not change. For women, both in urban and rural areas, the main causes were cancers, cardiovascular diseases and external causes.

The biggest differences in premature mortality between urban and rural residents occurred due to external causes, and in 2011 it was higher in rural inhabitants, among women by $8 \%$ and among men by $29 \%$. Traffic accidences and suicides were the leading external causes of PYLL. In the study period, the PYLL rate for traffic accidences decreased in urban and rural areas among men and women. However, the change was faster in urban areas which caused an increase in the differences in premature mortality due to external 
causes. Variations in premature mortality between urban and rural areas also increased for suicide in both genders. Unfortunately, the PYLL rate for suicides among men in rural areas increased by $9.0 \%$; in urban areas, whereas the PYLL rate decreased by $12.9 \%$. Premature mortality for this reason significantly decreased only among women in urban areas.

The results of the presented study are consistent with those of Kułaga et al., which show that in 1999-2006, mortality due to suicides increased among rural adolescent boys by $9.5 \%$ per year, and decreased by $4.2 \%$ per year in urban areas [29]. The results obtained by the researches indicates for the need for a public health strategy which includes a target in the reduction of suicides, and aimed at the high risk group - young men living in rural areas.

Premature mortality due to cardiovascular diseases in Poland has declined since 1991 [20], as confirmed by the current study. The trends were similar in urban and rural inhabitants. During the period under analysis, the rate of PYLL due to ischemic heart diseases and cerebrovascular diseases among men and women decreased in both populations. Premature mortality from cardiovascular diseases can be prevented through a healthier lifestyle and timely access to medical treatment. According to a Polish study on the decline in mortality from coronary heart disease after socioeconomic transformation, over half of the reduction in mortality was associated with favourable changes in major cardiovascular risk factors, and about a third was attributable to modern treatments [30]. The results of the presented study indicate that changes in the factors influencing premature mortality due to cardiovascular diseases are similar in urban and rural areas.

The results of the research show that the PYLL rate due to overall cancers since 2002 has decreased for men and women in both urban and rural areas. However, unfavourable changes were prevalent for lung cancer and colorectal cancer among women in rural areas. There was a favourable and statistically significant change for lung cancer in men and breast and cervical cancer in women. Among men, premature mortality from all cancers and lung cancer was higher in rural areas than urban. Among women, the PYLL rate from all analysed cancers was higher among women in urban areas.

In Poland, lung cancer is still the leading cause of deaths; however, the trends are different for each gender. Among men, the general mortality trend has decreased slowly, whereas among women it has increased rapidly. Similar changes, especially in the female population, have also been noticed in many EU countries [31]. In other countries, for example: France, Spain and Italy, the trend is either stable or has decreased [32]. The results of the research indicate a reduction in the inequalities in premature mortality from lung cancer among women between urban and rural areas from $53 \%$ to $17 \%$. Unfortunately, this was due to an increase in the of PYLL rate by $25.7 \%$ in rural areas. The results of Global Adult Tobacco Survey (GATS) in Poland showed that in 2009-2010, daily smoking among men did not differ between urban $(34.2 \%)$ and rural $(32.2 \%)$ areas, but among women it was higher in urban (23.5\%) areas (rural - 16.8\%) [33], which was reflected in higher premature mortality due to lung cancer in urban areas. The results of trends analysis in the current study and studies published for the country, show that measures undertaken to fight tobacco smoking have had a certain favourable influence among men; however, they have had little effect among women. At the beginning of the 1990s in Poland, $50.5 \%$ of adult men and $26.1 \%$ women smoked daily; in 2009-2011, the percentage was 35.1\% for men and 22.1 for women [33].

In the last 30 years in Poland, the incidence and mortality due to colorectal cancer have increased. Among men, the increase occurred fastest as far as cancers are concerned [34]. The results of the presented study show that the trend in premature mortality has changed significant only among men in urban areas - decreased by $0.9 \%$ per year. The risk of death due to colorectal cancer in Poland, the Czech Republic, Slovakia and Hungary, is among the highest in Europe, and the divergence between Poland and North-West European countries is increasing systematically [35].

Premature deaths due to colorectal cancer are preventable through intensified primary prevention based on modification of risk factors related to lifestyle, secondary prevention based on colonoscopy and faecal occult blood tests, and finally, the improvement of standards of diagnosis and treatment. Population screenings carried out in the 1990s, however, showed that standards of diagnosis and treatment were rarely followed [36].

Cervical cancer is a cancer which can also be effectively prevented, and Poland is a country of mid/high risk of incidence and mortality due to this cancer. In Europe, the risk is higher in Romania and Bulgaria. Although in Poland general mortality due to cervical cancer decreases, the divergence between Poland and Western European countries does not diminish [37]. One of the main reasons for this situation is the low attendance rate in the Polish Cervical Cancer Screening Programme. The results of the presented study indicate that premature mortality due to cervical cancer is higher among women living in urban areas by about $27 \%$, which may be related to lower participation in the screening by women living in urban areas [38].

The presented results show that the premature mortality trend due to cervical cancer in urban and rural population was similar to the general mortality trend, which was also too slow, and calls for the need of intensification of prevention and improvement of treatment standards.

The results of this study confirm that premature mortality due to breast cancer is also higher in the urban female population. The PYLL rate in urban areas was about $17 \%$ higher than in rural areas. The traditional mortality rate in 2002-2011 among urban women was higher by about 26\% than in rural areas, but in the young age group (15-49), the differences were smaller and amounted to $15 \%$ [39]. Research carried out in Europe [40, 41], North America [42] and Australia [43] confirm that the risk of breast cancer is related to urbanization and improvement in living conditions. The dissemination of an 'urban lifestyle' is characterized by high exposure to breast cancer incidence risks which are linked to the lifestyle. The higher premature mortality in urban areas than in rural areas is reflected with a higher incidence rate. Research conducted at the beginning of the 21st century in Małopolskie and Podlaskie Provinces of Poland showed a higher breast cancer incidence among female population in urban areas - the urban/ rural ratio was 1.5 and 1.4 , respectively $[44,45]$. In Lodz Province in 2008 , the breast cancer mortality rate was $41 \%$ higher among urban residents [5].

The results of the presented study also confirm a similar decrease in premature mortality due to breast cancer in both 
populations, which amounted to $1.7 \%$ per year in urban and $1.5 \%$ in rural areas. In Poland, the traditional mortality rate in 2002-2011 among urban women decreased significant by $1.0 \%$ per year, but among rural women the trend remained unchanged. However, in the youngest age group, mortality significantly decreased both in urban (4\% per year) and rural (2.3\% per year) areas [39]. In the European Union countries, such as Germany or the UK, the traditional mortality rate due to breast cancer has been decreasing since the end of the 1980s. In Poland, a decrease in mortality has been observed since the mid-1990s. In 2000-2008, in France, Germany and Italy, mortality due to breast cancer decreased by $1.5-1.8 \%$ per year. In Spain and the UK, the decrease in mortality amounted to approximately $2.4 \%$ per year. In the same period in Poland, mortality decreased slightly $-0.2 \%$ per year [46].

In many countries in Europe, North America and Australia, breast cancer risk has decreased [47]. Progress in breast cancer control results from dissemination of population cancer screening programmes for early detection based on mammography, which has contributed to an increase in the proportion of patients diagnosed with breast cancer and treated at its early stage. At the same time, development of effective diagnostic methods and improvement in treatment standards, as well as access to the newest drugs, contributed to the improvement of patients' prognosis at all cancer stages [48].

In the majority of highly developed countries, deaths due to cardiovascular diseases, cancers and external reasons, constitute over $70 \%$ of potential years of life lost before the age of 70, for both men and women [49]. In most cases, these deaths are preventable, thanks to measures undertaken in the field of health promotion, social education, early detection of diseases, and effective treatment. It is important to know the magnitude and causes of premature mortality in different populations for the purposes of social planning and public health decision making. Moreover, analysis of premature mortality in urban and rural areas provides important insights into the role of health-policy interventions and of behavioural and healthcare factors, such as obesity, smoking, physical activity, and differential access to health services, as well as changing socioeconomic conditions. Such an analysis is also important for allocating critical social and public health resources towards those in rural or urban areas who may be at higher risk of premature mortality from major chronic conditions and external causes.

\section{CONCLUSIONS}

The results of the presented study show the following:

1. The place of residence affects men and women in a different way. Premature morality among men was markedly higher in the rural population for all analysed causes, except for colorectal cancer and ischemic heart diseases. Among women, premature mortality was higher in urban areas, except for external causes, traffic accidents, suicides and cerebrovascular diseases.

2. The largest differences in premature mortality between urban and rural residents occurred due to external causes, traffic accidents and suicides in men, and traffic accidents and suicides in women.

3. Among men, in both populations, for all analysed groups of deaths except for suicides in rural areas, favourable changes were noted. Among women, also in urban and rural areas, favourable changes were noted for all analysed groups of deaths, except for lung cancer among women in rural areas.

4. The presented epidemiological situation for premature mortality in Poland shows that in the majority of cases it is caused by preventable deaths, which leads to a need to intensify measures in primary and secondary prevention.

\section{REFERENCES}

1. Xavier A, Price Ch, von Nordheim F. Solidarity in health. The European Commission sets out new actions on health inequalities. Eurohealth 2009; 15(3): 1-4.

2. Mackenbach JP, Stirbu I, Roskam AJR, Schaap MM, Menvielle G, Leinsalu M, et al. Socioeconomic inequalities in health in 22 countries. N Engl J Med. 2008, 358: 2468-2481.

3. World Health Organization Regional Office for Europe. Social inequalities in health in Poland. http://www.euro.who.int/__data/ assets/pdf_file/0008/177875/E96720.pdf (access: 2015.03.20).

4. Whitehead M, Dahlgren G. Concepts and principles for tackling social inequities in health: levelling up part 1. Copenhagen, WHO Regional Office for Europe, 2007. http://www.euro.who.int/__data/ assets/pdf_ file/0010/74737/E89383.pdf (access: 2015.03.20).

5. Maniecka-Bryła I, Pikala M, Bryła M. Health inequalities among rural and urban inhabitants of Łódz Province, Poland. Ann Agric Environ Med. 2010; 19(4): 723-31.

6. Lipowicz A. Disparities in health status between rural and urban adult males in Lower Silesia, Poland. Anthropol Anz. 2015; 72(1): 13-25.

7. Krzyżak M, Maślach D, Bielska-Lasota M, Juczewska M, Rabczenko D, Marcinkowski JT, et al. Breast cancer survival gap between urban and rural female population in Podlaskie voivodship, Poland, in 20012002. Population study. Ann Agric Environ Med. 2010; 17: 277-282.

8. Maślach D, Krzyżak M, Szpak A, Owoc A, Bielska-Lasota M. Waiting time for treatment of women with breast cancer in Podlaskie Voivodeship (Poland) in view of place of residence. A population study. Ann Agric Environ Med. 2013; 20(1): 161-166.

9. Narodowy Program Zdrowia na lata 2007-2015. http://www.mz.gov. pl/__data/assets/pdf_file/0020/12494/zal_urm_npz_90_15052007p. pdf (access: 2015.03.20).

10. Topór-Mądry R, Gilis-Januszewska A, Kukiewicz J, Pająk A. Szacowanie potrzeb zdrowotnych. Uniw Wydaw Med. „Vesalius”, Kraków 2002: $37-43$.

11. Gromulska L, Wysocki MJ, Goryński P. Lata przeżyte w zdrowiu (Healthy life years, HLY) - zalecany przez Unię Europejska syntetyczny wskaźnik sytuacji zdrowotnej ludności. Przegl Epidemiol. 2008; 62: 811-820.

12. Romeder J, McWhinnie J. Potential Years of Life Lost Between Ages 1 and 70: An Indicator of Premature Mortality for Health Planning. Int J Epidemiol. 1977; 6: 143-151.

13. Gardner J. Sanborn J. Years of potential life lost (YPLL) - what does it measure? Epidemiology 1990; 1: 322-329.

14. Health at a Glance 2011: OECD Indicators. OECD Publishing. http:// www.oecd-ilibrary.org/social-issues-migration-health/health-at-aglance-2011_health_glance-2011-en_(access: 2015.03.20).

15. World Health Organization. International Statistical Classification of Diseases and Health Related Problems: tenth revision. 2nd edition. Geneva 2004.

16. http://stat.gov.pl/bdl/app/dane_podgrup.display?p_id=914730\&p_ token $=0.23592747352086008$ (access: 2015.03.22).

17. Kim HJ, Fay MP, Feuer EJ, Midthune DN. Permutation tests for joinpoint regression with applications to cancer rates. Stat Med. 2000; 19: 335-351 (correction: 2001; 20: 655).

18. Joinpoint Regression Program. Version 4.0.4. May 2013; Statistical Research and Applications Branch. National Cancer Institute.

19. Health Disparities Calculator, Version 1.2.4. 2013; Division of Cancer Control and Population Sciences, National Cancer Institute.

20. Zatoński W. Evaluation of health in Poland since 1988. Centrum Onkologii - Instytut. Warszawa, 1996: 13-19.

21. Mainous A, Kohrs F. A comparison of health status between rural and urban adults. J Commun Health. 1995; 20: 423-431.

22. Senior, M, Williams H. Higgs G. Urban-rural mortality differentials: controlling for material deprivation. Soc Sci Med. 2000; 51: 289-305.

23. Singh GK, Siahpush M. Widening rural-urban disparities in all-cause mortality and mortality from major causes of death in the USA, 19692009. J Urban Health. 2014; 91(2): 272-292. 
24. Bobak M, Pikhart H, Pajak A, Kubinova R, Malyuyina S, Sebakova H, et al. Depressive symptoms in urban population samples in Russia, Poland and the Czech Republic. B J Psychiatry 2006; 188: 359-365.

25. Leinsalu M, Stirbu I, Vågerö D, Kalèdienè R, Kovàcs K, Wojtyniak B, et al. Educational inequalities in mortality in four Eastern European countries divergence in trends during the post-communist transition from 1990 to 2000. Int J Epidemiol. 2009; 38: 512-525.

26. Kalediene R, Petrauskiene J. Socio-economic transition, inequality, and mortality in Lithuania. Econ Hum Biol. 2004; 2: 87-95.

27. Colin M, Thies B, Doris MF. Global burden of Disease: update 2004. In Edition World Health Organisation, 2004.

28. Wojtyniak B, Wysocki M. Wybrane aspekty sytuacji demograficznospołecznej. In: Wojtyniak B, Goryński P, Moskalewicz B (eds.). Sytuacja zdrowotna ludności Polski i jej uwarunkowania. Narodowy Instytut Zdrowia Publicznego. Warszawa. 2012, p. 58-59.

29. Kułaga Z, Litwin M, Wójcik P, Jakubowska-Winecka A, Grajda A, Gurzkowska B, et al. Przyczyny i nasilenie zgonów dzieci wiejskich w latach 1999-2006 - porównanie z dziećmi miejskimi. Med Ogól. 2010; 16 (XLV): 63-75.

30. Bandosz P, O’Flaherty M, Drygas W, Rutkowski M, Koziarek J, Wyrzykowski B, et al. Decline in mortality from coronary heart disease in Poland after socioeconomic transformation: modelling study. BMJ, 2012; 344: d8136 doi: 10.1136/bmj.d8136.

31. Tyczyński JE, Bray F, Aareleid T. Lung cancer mortality patterns in selected Central. Eastern and Southern European countries. Int J Cancer.2004; 109: 598-610.

32. Bosetti C, Malvezzi M, Rosso T, Bertuccio P, Gallus S, Chatenoud L, et al. Lung cancer mortality in European women: trends and predictions. Lung Cancer. 2012; 78: 171-178.

33. Ministerstwo Zdrowia, World Health Organization Regional Officer for Europe. Globalny sondaż dotyczący używania tytoniu przez osoby dorosłe (GATS) Polska 2009-2010.

34. Didkowska J, Wojciechowska U, Zatoński W. Nowotwory złośliwe w Polsce w 2009 roku. Centrum Onkologii Instytut. Warszawa, 2000.

35. Bosetti C, Levi F, Rosato V, Bertuccio P, Lucchini F, Negri E, et al Recent trends in colorectal cancer mortality in Europe. Int J Cancer. 2011; 129; 180-191.

36. Gatta G, Zigon G, Aareleid T, Ardanaz E, Bielska-Lasota M, Galceran J, et al. Patterns of care for European colorectal cancer patients diagnosed 1996-1998: a EUROCARE High Resolution Study. Acta Oncol. 2010; 49: $776-783$.
37. Arbyn M, Raifu A, Weiderpass E, Bray F, Anttila A. Trends of cervical cancer mortality in the member states. Eur J Cancer. 2009; 45: 26402648.

38. Spaczyński M, Karowicz-Bilinska A, Rokita W, Molińska-Glura M, Januszek-Michalecka L, et al. Attendance rate in the Polish Cervical Cancer Screening Program in the years 2007-2009. Ginekol Pol. 2010; 81: 655-663.

39. Krzyżak M, Maślach D, Pogorzelska P, Piekutowska S, Szpak A. Breast cancer mortality in urban and rural femal population in Poland in years 2002-2011. Zdr Publ. 2013; 123(4): 273-276.

40. Fnis S, Storm HH. Urban-rural variation in cancer incidence in Denmark 1943-1987. Eur J Cancer. 1993; 29A: 538-44.

41. Smailyte G, Kurtinaitis J. Cancer mortality differences among urban and rural residents in Lithuania. BMC Public Health. 2008; 8:56. http:// www.biomedcentral.com/1471-2458/8/56 (access: 2015.03.26).

42. Howe HL, Keller JE, Lehnherr M. Relation between population density and cancer incidence, Illinois, 1986-1990. Am J Epidemiol. 1993; 138: 29-36.

43. Yu XQ, O'Connell DL, Gibberd RW, Armstrong BK. Assessing the impact of socio-economic status on cancer survival in New South Wales, Australia 1996-2001. Cancer Causes Control. 2008; 19: 13831390.

44. Rachtan J, Sokołowska A, Geleta M, Molong Ł. Zachorowalność na nowotwory złośliwe piersi u kobiet w województwie małopolskim w latach 1999-2001. Współcz Onkol. 2008; 9: 425-428.

45. Krzyżak M, Maślach D, Juczewska M, Lasota W, Rabczenko D, Marcinkowski JT, et al. Differences in breast cancer incidence and stage distribution between urban and rural female population in Podlaskie Voivodship, Poland in years 2001-2002. Ann Agric Environ Med. 2010; 17: 159-62.

46. Bosetti C, Bertuccio P, Levi F, Chatenoud L, Negri E, La Vecchia C. The decline in breast cancer mortality in Europe: An update (to 2009). The Breast. 2012; 21: 77-82.

47. Curado MP, Edwards B, Shin HR, Storm H, Feray J, Heanue M, et al. Cancer Incidence in Five Continents. Vol. IX. IARC Scientific Publication No. 160. IARC. Lyon; 2007.

48. Boyle P, Levin B. World Cancer Report. IARC/WHO. Lyon; 2008.

49. Savidan A, Junker Ch, Cerny T, Ess S, et al. Premature mortality in Switzerland from 1995-2006: causes and trends. Swiss Med Wkly. 2010; 140: w13077. doi: 10.4414/smw.2010.13077. 